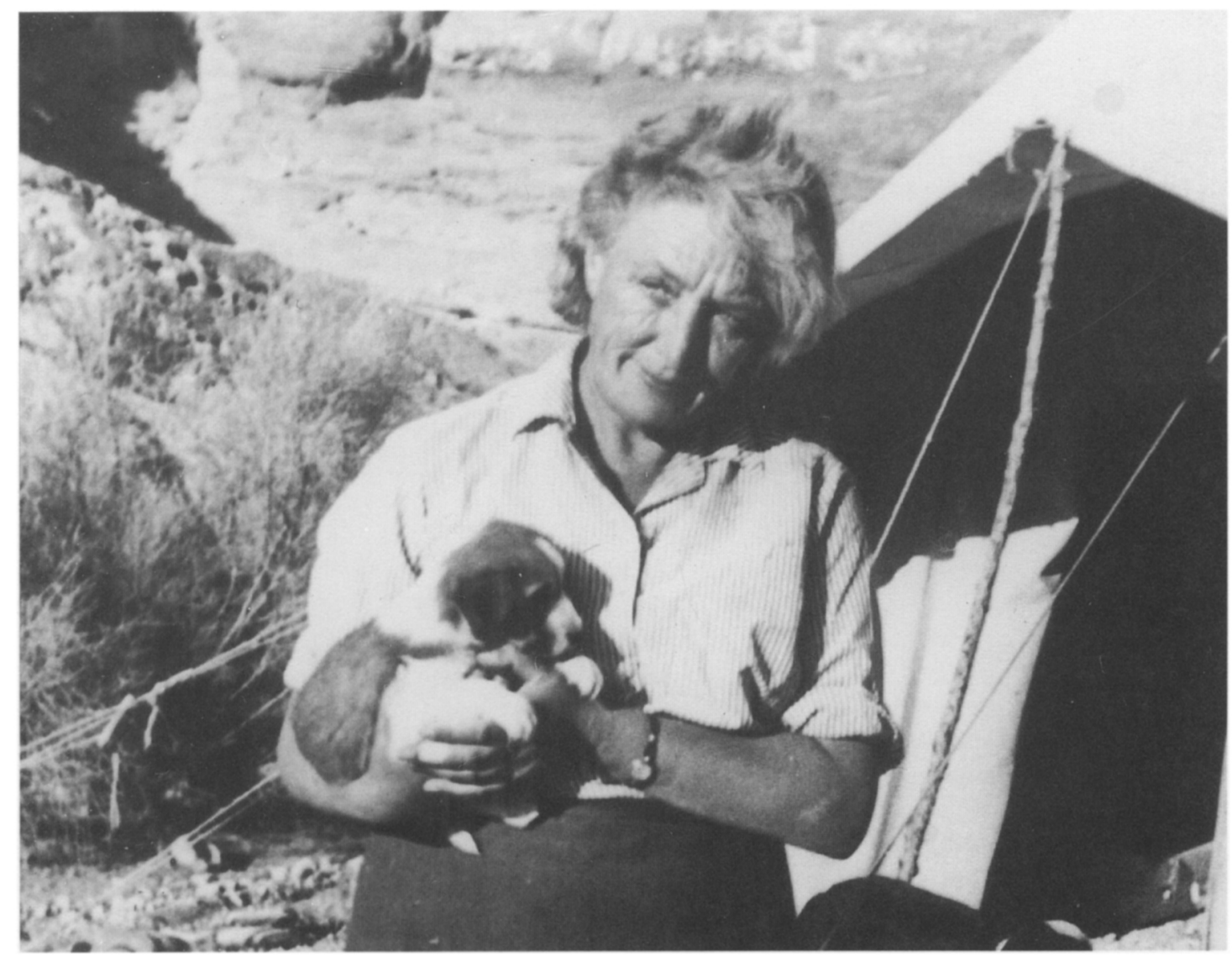

\title{
DIANA KIRKBRIDE-HELBAEK
} 1915-1997

The School's Director for the years 1970-1975, Diana Kirkbride-Helbaek, died in Aarhus on 13th August 1997, at the age of 81. Diana Victoria Warcup Kirkbride was one of the first students of Western Asiatic archaeology under Kenyon and Mallowan at the Institute of Archaeology in London, and was already a well-known personality in Near Eastern archaeology when she was appointed to the Directorship of the British School of Archaeology in Iraq, in succession to David Oates. A long obituary notice by Karen I. Wright appeared in the Independent newspaper for 5th September 1997. She had worked in Cyprus, Palestine, Lebanon, and especially Jordan, where her discovery and large-scale excavation of Beidha had transformed views of the earlier Neolithic of the Near East. Diana was not one to sit on her laurels, and immediately on arrival in Iraq she was in the field looking for a promising site. Her liking for the desert, and her knowledge of the Neolithic of the Levant naturally drew her westwards, and after a survey of sites in the Hatra region, her choice fell on Umm Dabaghiyah, where she worked for four seasons (1971-1974). Despite her initial disgust when it transpired that what she had intended to be an aceramic site had plenty of pottery, the site well repaid her labours, and her account of it in 50 years of Mesopotamian discovery makes fascinating reading.

The four levels of the mound were meticulously dug and recorded to her own high standards, and proved to conceal a number of surprises, including sophisticated domestic architecture with built-in chimneys and wall-paintings, and a large structure with more than 100 small cells and a vast quantity of onager bones. It was fortunate that the Soviet expedition to Yarim Tepe was investigating sites of approximately the same early or pre-Hassuna date (e.g. Tell Sotto and 
Maghzaliyah) at the same time, since this not only helped to place Umm Dabaghiyah in the wider sequence, but also to emphasise its very special nature. Whether or not the settlement was a tanning installation for onager hides, there is no doubt that the cellular building at the core of the site betrays a culture with a much higher level of organization and specialization than anyone would have predicted for this time and place-not unlike Beidha itself.

Diana very much liked the desert environment and the bedu tribes who worked for her at the site. She was happy to pay annual "sheikh money" to ensure the respect of the locals, and was vociferous in support of their way of life, convinced of the health benefits of regular changes of camp site. In Baghdad Diana lived at first in 76/1 Karradet Mariam, before the rickety state of that building (which was later completely demolished by an Iranian rocket) led her to move next door to the hostel at 90/1. Her time coincided with Theodora Newbould, as Secretary, and the Balfour-Pauls in the Embassy, with whom she shared memories of Palestine and Jordan. Her husband, Hans Helbaek, who had been at Beidha and whom she married shortly before coming to Iraq, remained in Denmark, and one of the benefits of retirement at the age of 60 was to allow her to spend more time with him. Another was the opportunity to resume her engagement with Beidha, where a final field season was arranged in 1983. During this time, and after Hans' death, Diana lived in Aarhus, with the generous benefits and support of the Danish state, and much kindness and attention from Peder and Inge Mortensen, both of whom had been invaluable members of the team in the first season at Umm Dabaghiyah. Life at Aarhus was punctuated by frequent visits to London, where, from the University Women's Club, she renewed her contacts with colleagues from the Middle East, and plotted further fieldwork.

During the 80's and 90's the publication of both Beidha and Umm Dabaghiyah has been taking shape. The documentation for Umm Dabaghiyah came back to Denmark in excellent shape, with all necessary photos, plans, sections, and object and pottery drawings. In 1992 Diana agreed to entrust the task of bringing this into print to Dr Stuart Campbell; the work is now well advanced, and it is only sad that she has not lived to see the finished product, which will undoubtedly be very impressive.

J. N. Postgate 